\title{
Kuasa Anak atas Perkawinan: Harmonisasi Perlindungan Anak dan Doktrin Fikih dalam Putusan Dispensasi Kawin
}

\author{
Muhammad Idris Nasution', Muhammad Syukri Albani Nasution² \\ ${ }^{1}$ Universitas Islam Negeri Sumatera Utara, Medan - Indonesia \\ ${ }^{2}$ Universitas Islam Negeri Sumatera Utara, Medan - Indonesia \\ Email Penulis: ${ }^{1}$ malimkadir@gmail.com, ${ }^{2}$ syukrialbani@yahoo.co.id
}

\section{Article Information}

\begin{tabular}{llll}
\hline Submitted & $: 2021-03-05$ & Revision & $: 2021-11-17$ \\
Reviewed & $: 2021-10-30$ & Published & $: 2021-11-30$ \\
\hline
\end{tabular}

\begin{abstract}
Child marriage is a global phenomenon that often neglects the protection of children's rights, but a few parents use the jurisprudence doctrine as a shield against their actions. The fiqh doctrine that gives absolute power (ijbar) to fathers and grandfathers over their children's marriages is often abused to marry off children even without their consent. The voice of a child is considered insignificant and his rejection of the actions of his parents is often seen as a form of iniquity. It is different from the two decisions of the Religious Courts, which the authors found, in which the decisions were more concerned with the child's opinion on the marriage that was planned for him by giving the child the rights of isti'dzan and isti'mar. Regarding this case, the authors conducted an analysis with the perspective of child protection and maqashid sharia. The results of the analysis show that in the perspective of child protection and maqashid sharia, children should be rewarded for their opinions. But this award is not enforced absolutely because the opinions of parents cannot be ignored, especially in cases where there is a very urgent reason. So that it is necessary to harmonize the protection of children's rights with the figh doctrine of guardian authority by considering the best interests of the child.
\end{abstract}

Keywords: Children's Rights, ljbar Power, Child Marriage, Marriage Dispensation

Abstrak: Perkawinan anak merupakan fenomena global yang seringkali mengabaikan perlindungan hak anak, tetapi segelintir orang tua menjadikan doktrin fikih sebagai tameng atas perbuatannya. Doktrin fikih yang memberikan kekuasaan absolut (ijbar) terhadap ayah dan kakek atas perkawinan anaknya kerap disalahgunakan untuk 
menikahkan anak meskipun tanpa persetujuannya. Suara anak dianggap tidak penting dan penolakannya terhadap tindakan orang tuanya sering sekali dianggap sebagai bentuk kedurhakaan. Berbeda dengan dua putusan Pengadilan Agama, yang penulis temukan, di mana dalam putusannya justru lebih mementingkan pendapat anak atas perkawinan yang telah direncanakan untuk dirinya dengan memberikan anak hak isti'dzan dan isti'mar. Terhadap kasus ini, penulis melakukan analisis dengan perspektif perlindungan anak dan maqashid syariah. Hasil analisis menunjukkan bahwa dalam perspektif perlindungan anak dan maqashid syariah, anak harus diberikan penghargaan atas pendapatnya. Tetapi penghargaan ini tidak diberlakukan secara mutlak karena pendapat orang tua tidak dapat diabaikan begitu saja apalagi dalam kasus telah adanya alasan sangat mendesak. Sehingga diperlukan harmonisasi antara perlindungan hak anak dengan doktrin fikih tentang otoritas wali dengan menimbang kepentingan terbaik untuk anak.

Kata Kunci: Hak Anak, Kuasa ljbar, Perkawinan Anak, Dispensasi Kawin

\section{Pendahuluan}

Perkawinan anak, yang secara umum didefinisikan sebagai perkawinan pertama seorang anak sebelum menginjak usia 18 tahun, merupakan fenomena yang terjadi di berbagai belahan dunia. Berdasarkan laporan UNICEF pada bulan Maret 2020, secara global tercatat sekitar 21 persen wanita muda menikah sebelum ulang tahun ke-18 mereka. Laporan tertinggi berasal dari Niger, di mana terdapat 76 persen wanita muda menikah sebelum usia 18 tahun (UNICEF, 2020). Di Indonesia, berdasarkan laporan BPS tahun 2018, tercatat 1 dari 9 perempuan berusia $20-24$ tahun melangsungkan perkawinan pertama sebelum usia 18 tahun atau sekitar 11,21 persen (BPS, 2020).

Kelompok-kelompok masyarakat tertentu menganggap perkawinan anak tak perlu dipersoalkan karena merupakan praktik tradisional yang diatur oleh hukum adat atau hukum agama (Gaffney-Rhys, 2012). Bahkan beberapa tokoh agama, seperti Syeikh Mohamed Ben Abderrahman Al Magraoui, tokoh agama Maroko, dan Sheikh Abdul-Majid al-Zindani, rektor Universitas Al-Eman Yaman melakukan penentangan terhadap pembatasan usia minimal perkawinan bagi anak (Gaffney-Rhys, 2011), yang mana merupakan salah satu bentuk usaha pencegahan perkawinan anak. Dalam catatan Al-Hakami dan McLaughlin (2016) sendiri, masih terdapat 75 negara di seluruh dunia yang tidak menetapkan batas minimum usia perkawinan alias memperkenankan praktik perkawinan anak. 
Dalam pandangan dunia internasional, praktik perkawinan anak dianggap melanggar hak asasi anak (Gaffney-Rhys, 2012; UNICEF \& UNFPA, 2017; Arthur, dkk, 2018). Hak anak untuk didengarkan pendapatnya, hak anak untuk mengembangkan diri, dan hak anak untuk bermain sesuai dengan usianya seringkali terampas oleh perkawinan anak yang dikehendaki oleh orang tuanya. Tidak dapat dipungkiri, di beberapa masyarakat, seperti Arab Saudi, ayah memiliki kuasa terhadap perkawinan anak (Al-Hakami dan McLaughlin, 2016). Dalam tradisi fikih sendiri, ulama-ulama memberikan kuasa ijbar kepada seorang ayah untuk menikahkan anaknya yang masih gadis meskipun tanpa kerelaannya (Ibnu Hazm, 1947; Syaukani, 2006; Jaziri, 1986), sehingga anak hampir atau bahkan tidak berkuasa sama sekali atas perkawinannya sendiri.

Pada beberapa kasus perkawinan anak, penulis pernah menemukan kasus yang terbukti di persidangan bahwa perkawinan itu hanya kehendak orang tua anak, sedangkan anak sendiri belum menginginkannya. Fakta ini juga yang ditemukan hakim Pengadilan Agama Soreang perkara Nomor 524/Pdt.P/2020/PA.Sor. Dalam kasus ini, orang tua kedua belah pihak telah setuju atas rencana pernikahan si anak, sedangkan anak menurut keterangannya tidak kuasa untuk menolak kehendak orang tuanya. Di Pengadilan Agama Buol kasus hampir serupa juga terungkap dalam perkara Nomor 30/Pdt.P/2019/PA.Buol, anak jelas sekali mengungkapkan bahwa kehendak perkawinannya adalah kehendak orang tuanya bukan kehendak dirinya sendiri.

Dalam kasus-kasus ini, hakim dihadapkan pada perdebatan fikih dan perlindungan anak; apakah akan melanggengkan wewenang ijbar orang tua atau kuasa anak atas perkawinannya (istidzan wa istimar). Pada kedua putusan tersebut, hakim menolak pemohonan dispensasi kawin yang diajukan oleh orang tua terhadap anaknya dengan pertimbangan bahwa perkawinan tersebut bukan atas kehendak anak tetapi merupakan kehendak orang tuanya semata. Dengan pertimbangan ini, hakim telah memberikan anak kuasa atas perkawinannya, dan di sisi lain telah mengabaikan doktrin fikih yang memberikan kuasa mutlak terhadap orang tua. Namun demikian, pertimbangan atas perkawinan anak harus mengharmonikan antara pendapat orang tua dan anak; penolakan anak tidak mutlak dijadikan alasan untuk menolak permohonan orang tua apalagi jika telah ditemukan alasan sangat mendesak.

Pada makalah ini, penulis terlebih dahulu akan menguraikan masalah kuasa anak dalam perkawinan menurut fikih serta menurut perspektif perlindungan anak 
dalam Konvensi hak-Hak Anak. Setelah itu, kasus pada Pengadilan Agama Soreang dan Buol akan dideskripsikan, kemudian dianalisis menggunakan perspektif perlindungan anak dan maqashid syariah untuk didiskusikan.Selanjutnya, penulis menawarkan diskusi bagaimana mengharmonikan antara perlindungan anak dan doktrin fikih.

\section{Kedudukan Wali dan Kuasa Anak dalam Perkawinan Anak Menurut Fikih}

Paling tidak ada tiga konsep fikih menyangkut persoalan perkawinan anak, yaitu ijbar, istidzan dan istimar. Tiga konsep berkaitan dengan ruang lingkup kuasa wali dan kuasa anak dalam perkawinan. Dalam tradisi Islam, tidak ada perkawinan kecuali dengan seorang wali. Kedudukan wali dalam perkawinan sangat penting. Wali nikah dalam perkawinan merupakan rukun yang harus dipenuhi bagi calon mempelai wanita yang bertindak untuk menikahkannya (Pasal $19 \mathrm{KHI}$ ). Wali dalam pernikahan merupakan orang yang keberadaannya menjadi pertimbangan keabsahan akad nikah, tanpa keberadaannya nikah tidak sah (Jaziri, 1986). Mayoritas ulama berpandangan bahwa akad nikah tidak sah tanpa wali (Syaukani, 2006).

Fikih memberikan wali kewenangan yang besar dalam menentukan pernikahan anaknya, terutama jika anak yang hendak dinikahkan tersebut masih berada di bawah umum (shagir aw shagirah), bahkan terhadap anak gadis meskipun telah dewasa. Wali tertentu diberikan wewenang ijbar, yaitu boleh menikahkan anak gadisnya tanpa meminta izinnya, yang mana merupakan pendapat Malik, Syafii, Laits, Ibnu Abi Laila, Ahmad, dan Ishak (Syaukani, 2006; Jaziri, 1986). Ibnu Rusyd (t.t) mengutip kesepakatan ulama bahwa seorang ayah memiliki wewenang ijbar untuk menikahkan anak laki-lakinya yang belum dewasa, begitupun anak perempuannya yang masih gadis dan belum dewasa, dan tidak perlu meminta pendapat mereka (wa la yasta'miruha). Pendapat serupa dikemukakan oleh Asy-Syirazi (t.t) dan AsySyarbini (2009) bahwa ayah dan kakek boleh menikahkan anak gadis meskipun tanpa kerelaannya, baik gadis tersebut masih kecil atau sudah dewasa. Hak isti'dzan atau permintaan izin diberikan kepada gadis kalau sudah dewasa, sedangkan hak istimar atau hak untuk dimintai pendapat diberikan kepada janda.

Deklarasi Universal Hak-Hak Asasi Manusia menentukan bahwa hak untuk menikah dan untuk membentuk keluarga terbatas pada laki-laki dan perempuan yang sudah dewasa, dengan tidak dibatasi kebangsaan, kewarganegaraan atau 
agama. Deklarasi ini membatasi hak pernikahan untuk orang dewasa. Ketentuan ini dapat dipahami karena sebuah perkawinan membutuhkan kedewasaan berupa kesiapan fisik dan kematangan mental demi terwujudnya tujuan perkawinan dan terbentuknya keluarga yang kekal.

Pembatasan perkawinan untuk orang dewasa dan pencegahan perkawinan anak merupakan bentuk perlindungan terhadap hak-hak anak. Konvensi Hak-Hak Anak yang disetujui oleh Majelis Umum PBB pada tanggal 20 November 1989, dan telah diratifikasi oleh Pemerintah Indonesia melalui Keputusan Presiden Nomor 36 Tahun 1990, menentukan bahwa anak adalah setiap manusia di bawah usia 18 tahun, kecuali apabila menurut hukum yang berlaku bagi anak tersebut ditentukan bahwa usia dewasa dicapai lebih awal. Konvensi ini mengatur bahwa setiap anak berhak untuk hidup, berhak untuk memperoleh sebuah nama serta untuk memperoleh kewarganegaraan, berhak atas kemerdekaan berpikir, berkeyakinan dan beragama, berhak untuk menikmati standar kesehatan tertinggi, berhak atas kehidupan yang layak untuk pengembangan fisik, mental, spiritual, moral dan sosialnya, berhak atas pendidikan, dan berhak untuk beristirahat dan bersantai, untuk bermain dan turut serta dalam kegiatan rekreasi yang sesuai dengan usia anak yang bersangkutan.

Perkawinan anak di sisi lain, menurut berbagai penelitian sangat rentan merampas hak-hak anak yang harus dilindungi ini. Anak perempuan berusia 10-14 tahun berisiko lima kali lipat meninggal saat hamil maupun bersalin dibandingkan kelompok usia 20-24 tahun, sementara risiko ini meningkat dua kali lipat pada kelompok usia 15-19 tahun (BPS, 2018). Wanita dewasa yang menikah saat masih anak-anak 1,41 kali lebih mungkin memiliki riwayat gangguan kejiwaan seumur hidup dibandingkan dengan wanita yang menikah di usia dewasa (Gage, 2013). Penelitian Field dan Ambrus (2008) menunjukkan bahwa institusi perkawinan remaja di negara berkembang menurunkan pendidikan perempuan. Jensen dan Thornton (2003) menemukan bahwa wanita yang menikah muda cenderung memiliki pendidikan yang lebih rendah dan mulai mengasuh anak lebih awal, dan memiliki lebih sedikit kekuatan pengambilan keputusan dalam rumah tangga. Mereka juga lebih mungkin mengalami kekerasan dalam rumah tangga.

Konvensi ini juga menentukan bahwa anak mempunyai hak untuk menyatakan pendapatnya secara bebas dalam semua hal yang mempengaruhi anak-anak tersebut, dan pendapat anak-anak dipertimbangkan sesuai dengan usia dan kematangan mereka. Dalam kasus perkawinan anak, menurut konvensi ini, anak bebas untuk berpendapat karena perkawinan tersebut akan sangat mempengaruhi 
kehidupannya, bahkan rentan merampas hak-haknya sebagaimana dikemukakan beberapa penelitian di atas. Ketentuan ini telah diakui pula dalam perubahan Undang-Undang Perkawinan di Indonesia.

Pada tahun 2019, Undang-Undang Perkawinan memperketat aturan terhadap perkawinan anak. Berawal dari Putusan Mahkamah Konstitusi Nomor 22/PUUXV/2017, Pemerintah dan DPR mengubah ketentuan Pasal 7 UU Nomor 1 Tahun 1974 tentang Perkawinan melalui UU Nomor 16 Tahun 2019. UU ini menentukan bahwa perkawinan hanya diizinkan apabila pria dan wanita sudah mencapai umur 19 (sembilan belas) tahun. Dalam hal terjadi penyimpangan terhadap ketentuan umur tersebut, orang tua pihak pria dan/atau orang tua pihak wanita dapat meminta dispensasi kepada Pengadilan dengan alasan sangat mendesak disertai bukti-bukti pendukung yang cukup. Di samping itu, terhadap pemberian dispensasi oleh Pengadilan tersebut wajib mendengarkan pendapat kedua belah calon mempelai yang akan melangsungkan perkawinan.

Perubahan UU ini kemudian direspon cepat oleh Mahkamah Agung Republik Indonesia dengan menerbitkan Peraturan Mahkamah Agung (PERMA) Nomor 5 Tahun 2019 tentang Pedoman Mengadili Permohonan Dispensasi Kawin. Dalam PERMA ini, dalam mengadili permohonan dispensasi kawin, Hakim harus mempertimbangkan asas kepentingan terbaik untuk anak, hak hidup dan tumbuh kembang anak, penghargaan atas pendapat anak, non-diskriminasi dan asas-asas penting lainnya dalam perlindungan anak. Sesuai dengan ketentuan UU Perkawinan juga, Hakim harus mendengarkan keterangan anak dan mempertimbangkannya. Pasal 13 bahkan menegaskan, jika Hakim tidak melaksanakan ketentuan tersebut mengakibatkan penetapan batal demi hukum.

Sebelum lahirnya peraturan-peraturan ini, pengadilan tidak diharuskan untuk menghadirkan anak atau mempertimbangkan keterangan anak. Sehingga dalam banyak perkara permohonan dispensasi kawin, anak tidak dihadirkan ke pengadilan dan tidak didengarkan pendapatnya. Namun setelah perubahan UU Perkawinan diiringi dengan terbitnya PERMA Dispensasi Kawin ini, pengadilan harus mendengarkan dan mempertimbangkan pendapat anak terkait perkawinan yang akan dijalaninya. Dalam hal ini, Pengadilan Agama dapat berperan siginifikan dalam mengurangi laju perkawinan anak di Indonesia, meskipun harus diakui bukan satu-satunya lembaga yang harus bertanggung jawab, karena persoalan perkawinan anak ini adalah persoalan yang sangat kompleks terhadap pemenuhan hak-hak anak. 


\section{Menimbang Pendapat Anak dalam Putusan Dispensasi Kawin}

Pengadilan Agama Soreang menerima permohonan dispensasi nikah untuk anak para pemohon yang terdaftar dengan nomor register 524/Pdt.P/2020/PA.Sor. Permohonan para Pemohon pada pokoknya adalah mohon agar para Pemohon diberikan dispensasi untuk menikahkan anak para Pemohon bernama Caca Hoerunisa dengan calon suaminya, sebab anak para Pemohon belum mencapai usia 19 tahun, yakni berusia 17 tahun. Setelah melalui proses pembuktian, Hakim menemukan fakta-fakta sebagai berikut:

- Bahwa permohonan para Pemohon untuk menikahkan anaknya bernama Caca Hoerunisa dengan calon suaminya bernama Opik Sudrajat telah ditolak oleh Kantor Urusan Agama Kecamatan Rancabali Kabupaten Bandung karena usia anak para Pemohon kurang dari 19 tahun;

- Bahwa anak para Pemohon berusia 17 tahun;

- Bahwa kedua pihak keluarga sudah sepakat dan tidak ada yang keberatan perihal perkawinan Caca Hoerunisa dan Opik Sudrajat;

- Bahwa anak para Pemohon mengetahui rencana perkawinan yang disetujui kedua pihak keluarga namun tidak berani untuk menolak keinginan keluarga tersebut;

- Bahwa calon suami Pemohon sudah mempunyai pekerjaan dan penghasilan untuk menafkahi;

- Bahwa antara anak para Pemohon dengan calon suaminya tidak ada hubungan darah, hubungan semenda ataupun hubungan sesusuan;

Terhadap fakta-fakta persidangan tersebut, Hakim dalam perkara ini mempertimbangkan bahwa telah terungkap bahwa anak para Pemohon masih di bawah umur serta masih berkeinginan untuk mengembangkan diri menuju kedewasaan dan kepribadian yang matang sehingga kelak dalam menjalani perkawinan dapat menjadi ibu rumah tangga yang baik dan bertanggungjawab menjaga keberlangsungan rumah tangga yang baik. Hubungan antara anak Para Pemohon dan calon suami juga baru terjalin sekira satu minggu sehingga hakim berpandangan bahwa bagi keduanya masih diperlukan saling mengetahui dan memahami karakter sikap masing-masing guna bekal membangun keluarga mereka di kemudian hari.

Atas dasar itu, hakim berkesimpulan bahwa permohonan para Pemohon tidak sesuai dengan ketentuan Pasal 6 ayat (1) Undang-Undang Nomor 1 Tahun 
1974 Tentang Perkawinan dan sejalan dengan hal tersebut hakim memandang perlu untuk mengutip pendapat dalam kitab al-Fiqh al-Islamy wa Adillatuhu juz 7 halaman 78 yang menyatakan bahwa tidak sah perkawinan tanpa adanya kerelaan dari kedua belah pihak yang berakad. Hal mana ketentuan tersebut didasarkan pada dalil hadits yang mengisahkan seorang sahabt wanita bernama Khansa binti Khidam yang mengadu kepada Rasulullah karena dinikahkan oleh ayahnya dengan lakilaki bukan pilihannya lalu Rasulullah menganulir hal tersebut dan mengembalikan kepada keputusan Khansa untuk memilih pasangan yang ia kehendaki. Akhirnya berdasarkan pertimbangan-pertimbangan, hakim berkesimpulan bahwa atas permohonan para Pemohon tidak terdapat alasan sebagaimana ditentukan oleh peraturan perundangan dan hukum syara sehingga hakim berpendapat bahwa permohonan para Pemohon patut untuk dinyatakan ditolak.

Sementara kasus yang terjadi di Pengadilan Agama Buol, Pemohon dengan surat permohonannya tanggal 16 Mei 2019 yang didaftarkan di kepaniteraan Pengadilan Agama Buol dengan Nomor: 0030/Pdt.P/2019/PA.Buol, dalam pokok permohonannya menyebutkan akan menikahkan putri kandungnya, yang berstatus perawan dengan seorang laki-laki, namun karena anak Pemohon belum cukup umur dan maksud perkawinan tersebut telah ditolak oleh Pegawai Pencatat Nikah Kantor Urusan Agama Kecamatan Biau, Kabupaten Buol, sehingga Pemohon mengajukan permohonan dispensasi kawin ke Pengadilan Agama Buol.

Di persidangan, hakim mendengarkan keterangan dari kedua calon mempelai yang menyatakan bahwa pernikahan tersebut atas kehendak dari keluarga kedua belah pihak bukan dari kedua mempelai. Berdasarkan keterangan tersebut, hakim menilai Pemohon tidak dapat membuktikan dalil permohonannya bahwa kedua calon mempelai telah saling mengenal dan saling mencintai dan sepakat ke jenjang pernikahan dan pernikahan sangat mendesak untuk dilangsungkan karena hubungan keduanya telah sedemikian erat dan sangat sulit untuk dipisahkan, karena ternyata tidak sesuai dengan pernyataan kedua calon mempelai. Atas dasar itu, menurut hakim permohonan Pemohon harus dinyatakan ditolak.

\section{Penghargaan Pendapat Anak atas Perkawinan dalam Timbangan Perlindungan Anak dan Maqashid Syariah}

Kalau kasus-kasus di atas ditelaah menggunakan perspektif fikih, hakim dapat saja memutus untuk memberikan dispensasi kepada anak Pemohon meskipun 
rencana perkawinan tersebut bukan kehendak anak Pemohon. Pertama karena ada kuasa ijbar ayah sebagai Pemohon terhadap anaknya, di menurut kesepakatan ulama seorang ayah memiliki kuasa ijbar yakni kuasa untuk menikahkan anak gadisnya tanpa harus meminta izinnya terlebih dahulu (Ibnu Rusyd, t.t), atau tanpa kerelaannya sekalipun (Asy-Syirazi, t.t; Asy-Syarbini, 2009). Dalam kasus anak gadis telah dewasa, memang seorang wali tidak boleh memaksakan anaknya menikah dengan laki-laki yang tidak sekufu tanpa persetujuannya dan persetujuan seluruh walinya (Asy-Syirazi, t.t). Namun fakta persidangan menunjukkan bahwa ayahnya hendak menikahkannya dengan seorang laki-laki yang sekufu, dalam arti agamanya sama dengan anak dan telah pula bekerja dan berpenghasilan sehingga dianggap mampu mencukupi kebutuhan rumah tangga.

Terhadap kasus di atas, boleh dikatakan bahwa hakim telah melampaui pendapat-pendapat fikih. Hakim dalam kasus ini tidak saja memberikan anak hak isti'dzan dan istimar sekaligus, tetapi juga mempertimbangkan keduanya dalam penetapan. Adapun pendapat fikih yang dijadikan hakim Pengadilan Agama Soreang sebagai dalil penetapannya, menurut hemat penulis, itu masih dapat diperdebatkan karena al-aqidan, dua orang yang berakad dalam konteks pernikahan adalah antara laki-laki calon mempelai dengan wali calon mempelai perempuan, bukan antara calon pengantin laki-laki dan perempuan. Hakim dalam kasus telah memperluas hak isti'dzan dan isti'mar terhadap anak tidak saja kepada orang dewasa. Juga dengan menggunakan dalil fikih tersebut, hakim telah memperluas makna dua orang yang berakad, sebagaimana teksnya, berlaku juga terhadap calon mempelai wanita.

Dalam penetapannya, hakim merujuk ke beberapa pasal yang saling bersesuaian antara satu dengan yang lain. Pertama Pasal 7 ayat (3) Undang Undang Nomor 16 Tahun 2019 tentang Perubahan atas Undang Undang Nomor 1 Tahun 1974 Tentang Perkawinan yang menyatakan bahwa pemberian dispensasi oleh Pengadilan sebagaimana dimaksud pada ayat (2) wajib mendengarkan pendapat kedua calon mempelai yang akan melangsungkan perkawinan. Hakim juga mengutip Pasal 14 PERMA Nomor 5 Tahun 2019 Tentang Pedoman Mengadili Permohonan Dispensasi Kawin yang menyatakan dalam pemeriksaan di persidangan hakim mengidentifikasi Anak yang diajukan dalam permohonan mengetahui dan menyetujui rencana perkawinan. Kedua Pasal ini dikaitkan dengan Pasal 6 ayat (1) Undang-Undang Nomor 1 Tahun 1974 Tentang Perkawinan. Pasal ini menyatakan bahwa perkawinan didasarkan atas persetujuan kedua calon mempelai. Dengan demikian, hakim dalam perkara ini telah memperluas makna calon mempelai 
dalam UU Perkawinan mencakup juga persetujuan calon mempelai anak.

Pemberian anak kuasa atas perkawinannya ini meruntuhkan argumentasiargumentasi yang dipaparkan di dalam kitab-kitab fikih bahwa dalam perkara perkawinan anak maka wali lebih berhak atasnya. Argumen ini dibangun berdasarkan argumentum a contrario terhadap hadis Nabi, "Janda lebih berhak atas dirinya sendiri daripada walinya." Berdasarkan hadis ini beberapa ulama fikih menyimpulkan bahwa jika seorang janda lebih berhak atas dirinya daripada walinya, maka berarti terhadap seorang gadis, yang paling berhak adalah walinya (Asy-Syirazi, t.t; Syaukani, 2006).

Dalam kasus ini, hakim juga mengemukakan urgensinya memperhatikan hakhak anak dengan mengutip Pasal 2 PERMA Nomor 5 Tahun 2019 Tentang Pedoman Mengadili Permohonan Dispensasi Kawin, antara lain asas kepentingan terbaik bagi anak, hak hidup dan tumbuh kembang anak, penghargaan atas pendapat anak dan penghargaan atas harkat dan martabat manusia. Tetapi memang tidak ditemukan bagaimana hakim menerapakan asas-asas ini dalam penetapannya. Dalam telaah penulis, hakim terbatas mengkaitkannya dengan asas pernghargaan atas pendapat anak karena telah mempertimbangkan pendapat anak di persidangan sehingga menolak permohonan dispensasi nikah.

Pemberian anak kuasa atas perkawinannya sendiri telah sejalan dengan kemaslahatan anak dan maqashid atau tujuan dari perkawinan itu sendiri. Perkawinan anak sebagaimana telah disebutkan di muka cenderung berdampak negatif terhadap anak atau menjadi mafsadat bagi anak. Di samping itu pula, fakta persidangan menunjukkan belum terdapat alasan yang sangat mendesak untuk diselenggarakannya perkawinan, kecuali kehendak orang tua semata. Jadi tidak ditemukan alasan untuk lebih mengutamakan perkawinan tersebut daripada menolak mafsadat yang dikhawatirkan akan ditimbulkannya. Maka hal ini sesuai dengan qaidah fikih, "dar'u al-mafasid muqaddam 'ala jalbi al-mashalih."

Tujuan perkawinan ini sendiri adalah untuk membentuk keluarga yang bahagia dan kekal berdasarkan Ketuhanan yang Maha Esa (Pasal 1 UU Perkawinan). Dalam fikih maqashid, perkawinan merupakan salah satu bentuk pemenuhan maslahat hifzh an-nasl, dalam rangka menjaga keturunan. Dalam kasus ini implementasi maqashid ini justru dengan membiarkan keturunan, dalam hal ini anak pemohon, untuk melanjutkan pendidikannya, mengembangkan kepribadian dan kemampuan dirinya, serta memberikan hak-haknya sebagai anak yang lainnya. Dengan demikian, dia akan terjaga sesuai dengan maqashid syariah. Berbeda hal misalnya kalau si 
anak telah melanggar kesusilaan, tidak dapat lagi menahan diri dari pergaulan bebas menjurus sex, bahkan sudah berhubungan badan sebagaimana dalam banyak kasus, atau sudah hamil akibat pergaulannya tersebut. Dalam kasus-kasus seperti ini, perlu juga memperhatikan hifzh ad-din anak dan calonnya, serta memperhatikan hifzh an-nasl bagi anak yang sedang dikandungnya.

\section{Harmonisasi Doktrin Fikih dan Perlindungan Hak Anak dalam Perkara Dispensasi Kawin}

Bagaimana apabila dalam satu kasus dispensasi kawin telah terdapat alasan sangat mendesak tetapi anak menolak untuk dinikahkan? Undang-Undang Perkawinan menentukan bahwa jika terjadi penyimpangan umur perkawinan, orang tua pihak pria dan/atau orang tua pihak wanita dapat meminta dispensasi kepada Pengadilan dengan alasan sangat mendesak disertai bukti-bukti pendukung yang cukup. Kemudian, pemberian dispensasi oleh Pengadilan wajib mendengarkan pendapat kedua belah calon mempelai yang akan melangsungkan perkawinan. Dengan mencermati ketentuan undang-undang ini, aturan ini sangat menarik karena mencoba mengharmonikan antara kewenangan orang tua sebagai pihak pemohon, keberadaan alasan sangat mendesak perkara dan kewajiban mendengarkan pendapat anak. Dalam pemeriksaan perkara dispensasi kawin, ketiga aturan ini harus sama-sama dipertimbangkan.

Ketika orang tua yang memiliki legal standing atas perkara dispensasi kawin mengajukan permohonan dispensasi ke pengadilan, tanpa bisa membuktikan keberadaan alasan sangat mendesak dan tanpa persetujuan anak, sudah sepatutunya permohonan tersebut ditolak sebagaimana dalam kasus dua putusan Pengadilan Agama di atas. Ketika ada kasus anak sendiri mengajukan permohonan dispensasi ke pengadilan, padahal orang tuanya atau walinya masih hidup dan tidak ada halangan untuk menghadiri persidangan, meskipun misalnya terdapat alasan sangat mendesak untuk menikah, permohonan tersebut tidak akan diterima karena anak tidak memiliki legal standing dalam perkara ini. Ketika ada kasus orang tua mengajukan permohonan dispensasi ke pengadilan dan berhasil membuktikan adanya alasan sangat mendesak, tetapi anak menolak untuk menikah, bagaimana menyikapi kasus ini?

Kasus ini telah memenuhi syarat formil mengajukan permohonan dispensasi kawin karena orang tua sebagai pengaju memiliki legal standing, dan secara muatan 
perkara, permohonan dispensasi ini semestinya dapat dikabulkan karena telah terbukti ada alasan sangat mendesak. Tetapi di sisi lain, undang-undang menentukan wajib mendengarkan pendapat anak. Sehingga kasus ini terbentur antara kewajiban mendengarkan pendapat anak dengan keberadaan alasan sangat mendesak, yang dalam penjelasan undang-undang diartikan sebagai keadaan tidak ada pilihan lain dan sangat terpaksa harus dilangsungkan perkawinan.

Pemecahan kasus ini dapat dilakukan dengan beragam perspektif. Jika menggunakan perspektif fikih, kewajiban dapat ditinggalkan jika terbentur keadaan darurat. Penjelasan undang-undang tentang alasan sangat mendesak dalam ketentuan dispensasi kawin ini dalam perspektiffikih adalah kondisi darurat, dengan demikian kewajiban untuk mendengarkan pendapat anak dapat diabaikan karena tuntutan alasan sangat mendesak. Apalagi sebenarnya amanat undang-undang adalah untuk mendengarkan pendapat anak bukan untuk memutlakkan pendapat anak atas perkawinan. Kemudian persoalannya adalah interpretasi terhadap alasan sangat mendesak ini sangat beragam, maka dalam hal ini perlu pembatasan yang tegas terkait dengan alasan sangat mendesak ini. Menurut penulis, salah satu alasan sangat mendesak di sini adalah kehamilan calon mempelai perempuan. Dalam kondisi ini, menurut penulis lebih adil untuk menerima permohonan orang tua untuk menikahkan anaknya daripada menerima penolakan anak, sebagaimana kaidah irtikab akhaff ad-dhararain.

Menurut penulis, aspke paling penting untuk dipertimbangkan dalam perkara dispensasi kawin ini adalah aspek alasan sangat mendesak. Sementara kewenangan orang tua dalam mengajukan permohonan dan kewajiban pengadilan untuk mendengarkan pendapat anak ini dapat dikesampingkan dalam kasus-kasus tertentu secara spesifik. Sebagaimana dalam kasus di atas, menurut penulis tidak mengapa untuk berpaling dari penolakan anak demi menjaga kewajiban dharuri lainnya. Demikian pula dalam kasus anak sendiri sebagai pihak pemohon apabila orang tuanya enggan menikahkannya dan mengurusnya, padahal telah terdapat alasan sangat mendesak untuk menikah, maka dalam hal ini anak dapat diberikan legal standing untuk mengajukan perkaranya sendiri, meskipun akan bertabrakan dengan Undang-Undang Perkawinan dan Peraturan Mahkamah Agung tentang Dispensasi Kawin.

Dalam pandangan penulis, aturan tentang perkawinan anak melalui dispensasi kawin ini mesti dibaca secara fleksibel sesuai dengan sifat fleksibilitas hukum Islam itu sendiri. Hukum bergerak dinamis sesuai dengan keberadaan dan ketiadaan 
illatnya (al-hukm yadur ma'a 'illatih wujudan wa 'adaman). Hukum dapat berubahubah, secara fleksibel, berdasarkan perubahan waktu, tempat dan kondisi sosial (taghayyur al-ahkam bi taghayyur al-azminah wa al-amkinah wa al-urf wa al'awaid). Dengan demikian, tidak seharusnya ketentuan hukum diberlakukan secara kaku dan mutlak jika bertentangan dengan keadilan dan kemanfaatan hukum.

\section{Simpulan}

Dalam perkawinan, calon mempelai yang masih berusia anak perlu didengar pendapat dan persetujuannya (istidzan wa isti'mar) terhadap rencana perkawinan tersebut. Ketentuan ini telah sesuai dengan semangat Konvensi Hak-Hak Anak, Undang-Undang Perkawinan dan PERMA Dispensasi Kawin, meskipun telah menyimpang dari ketentuan fikih klasik yang memberikan ayah kekuasaan absolut atau ijbar terhadap perkawinan anak sebelum usia dewasa. Ketentuan peraturan perundang-undangan sesungguhnya telah mencoba mengharmonikan antara kewenangan orang tua dengan menjadikannya sebagai orang yang memiliki legal standing dalam mengajukan permohonan dispensasi kawin dan kewajiban pengadilan untuk mendengar pendapat calon mempelai terhadap perkawinan. Namun ketika dalam kasus-kasus tertentu ketentuan-ketentuan ini bertabrakan dengan alasan sangat mendesak dispensasi kawin, terhadap kedua ketentuan tersebut harus diterapkan secara fleksibel.

Sebagai rekomendasi dari makalah ini, para akademisi dapat mengembangkan dan meninjau ulang konsep istidzan dan istimar bagi anak dalam perkawinan, sekaligus melakukan tinjauan kritis terhadap konsep ijbar dalam perwalian. Bagi para praktisi, ulasan ini semoga dapat membantu dalam memecahkan berbagai kasus serupa dalam tema ini.

\section{Daftar pustaka}

Al-Hakami, H., \& McLaughlin, K. (2016). Debatable marriages: Marriage and child marriage in Saudi Arabia. Marriage \& Family Review, 52(7), 654-664.

Arthur, M., Earle, A., Raub, A., Vincent, I., Atabay, E., Latz, I., \& Heymann, J. (2018). Child marriage laws around the world: Minimum marriage age, legal exceptions, and gender disparities. Journal of women, politics \& policy, 39(1), 51-74. 
Badan Pusat Statistik dan Kementerian Pemberdayaan Perempuan dan Perlindungan Anak. (2018). Profil Anak Indonesia 2018. Jakarta: Kementerian Pemberdayaan Perempuan dan Perlindungan Anak.

Badan Pusat Statistik. (2020). Pencegahan Perkawinan Anak. Jakarta: Kementerian Perencanaan Pembangunan Nasional.

Field, E., \& Ambrus, A. (2008). Early marriage, age of menarche, and female schooling attainment in Bangladesh. Journal of political Economy, 116(5), 881-930.

Gaffney-Rhys, R. (2011). International law as an instrument to combat child marriage. The international journal of human rights, 15(3), 359-373.

Gaffney-Rhys, R. (2012). A comparison of child marriage and polygamy from a human rights perspective: are the arguments equally cogent?. Journal of Social Welfare and Family Law, 34(1), 49-61.

Gage, A. J. (2013). Association of child marriage with suicidal thoughts and attempts among adolescent girls in Ethiopia. Journal of Adolescent Health, 52(5), 654656.

Hazm, I. (1947). al-Muhalla, juz IX. Mesir: Muniriyah.

Jaziri, Abdur Rahman. (1986). Al-Fiqhala al-Mazahib al-Arba'ah. Beirut: Darul Fikr.

Jensen, R., \& Thornton, R. (2003). Early female marriage in the developing world. Gender \& Development, 11(2), 9-19.

Peraturan Mahkamah Agung (PERMA) Nomor 5 Tahun 2019 tentang Pedoman Mengadili Permohonan Dispensasi Kawin. 21 November 2019. Berita Negara Republik Indonesia Tahun 2019 Nomor 1489. Jakarta.

Syaukani, Muhammad bin Ali. (1427 H/2006 M). Nail al-Awthar min Asrar Muntaqa al-Akhbar. Arab Saudi: Dar Ibn al-Jauzi.

Undang-Undang Nomor 1 Tahun 1974 tentang Perkawinan. 2 Januari 1974. Lembaran Negara Republik Indonesia Tahun 1974 Nomor 1. Jakarta.

Undang-Undang Nomor 16 Tahun 2019 tentang Perubahan atas Undang-Undang Nomor 1 Tahun 1974 tentang Perkawinan. 15 Oktober 2019. Lembaran Negara Republik Indonesia Tahun 2019 Nomor 186. Jakarta.

Undang-Undang Nomor 23 Tahun 2002 tentang Perlindungan Anak. 22 Oktober 2002. Lembaran Negara Republik Indonesia Tahun 2002 Nomor 109. Jakarta. 
Undang-Undang Nomor 35 Tahun 2014 tentang Perubahan atas Undang-Undang Nomor 23 Tahun 2002 tentang Perlindungan Anak. 17 Oktober 2014. Lembaran Negara Republik Indonesia Tahun 2014 Nomor 297. Jakarta.

UNICEF \& UNFPA. 2017. Ending Child Marriage in Bangladesh. Diakses melalui https://asiapacific.unfpa.org/en/publications/ending-child-marriagebangladesh, Tanggal 11 November 2020 Pukul 14.49 WIB.

UNICEF. (2020). Child marriage around the world: Infographic. Diakses melalui https://www.unicef.org/stories/child-marriage-around-world, Tanggal 11/11/2020 Pukul 14.10 WIB. 
